\title{
不 定愁訴の良導帯治療
}

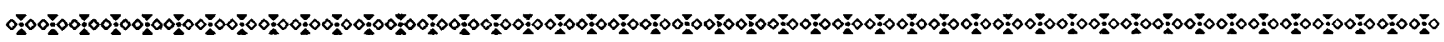

京都 安 田 治 三 郎

不定愁訴の患者は年々増加の傾向にある。 近来世界的に文化水準が急激に進歩し、人間 の生活様式が複雑化するにつれて、精神的又は 肉体的にストレスが蓄積され、これが最大の原 因となっているように思う。従って今後こうし た患者は益々増加するものと思はれるのである。 この種の患者が来たとき、私はカルテに不定 愁訴と書く場合と、そうでない場合がある。

患者は自ら不定愁訴とは言えないので、その 自賞症状をきいた上で診断を下すわけであるか ら、自覚症状が不定愁訴として最も適切である 場合と、少々疑問視される場合がある。たとえ ば、慢性頭痛、又は不眠等の一つの端的な症状 のみの場合は、頭痛又は不眠と書くのであるが、 その原因、経過等からみて知張り不定愁訴の一 つの症状であると気附く場合もあるのである。

不定愁訴の患者を男女別に比較してみると、 その比率は断然婦人に多く、男子には非常に少 い。

不定愁訴の症状は大体次の如きものが多い。

1. 頭痛 (偏頭痛) (後頭痛) 肩己り、頭重

2. 気分がいらいらして落付かない。不眠、不 安感。

3. 背、腰、胸その他に痛みがある。

4. 頻尿。

5. 便秘、又は下痢。

6. むかつく(吐気)。

7. 心悸允進。

8. 感情的になり易い...怒り易く、涙もろい。

9. 生理不順（生理痛）。

10.下肢、又は上肢の一部に痛みがある。
11. 消化不良、腹がはる。

12. 食欲減退。

13. 耳鳴り、のぼせ。

これ等の症状は全部揃って現はれるわけでは ない。このうちの二ッ乃至五つの症状のある場合 が多く、特に頭痛、肩こク、頭が重く鍋をかぶ ったようだとか、気分がいらいらして落付かず 仕事に自信がない。夜は少しも眠れない等の場 合が多い。

又、速脈、心悸儿進の状態をみることが多い のである。

次に消化器系統の機触障害も多い。食照不振 や便通の異状もよくある症状である。

この種の患者は精神状態が不安で、自分の健 康にも仕事にも自信が持てないような状態にな つている場合さえある。

だから先づ「この病気は必ず治る」という希 望を与えることが必要なのである。

これは仲々至難であるが治潦の都度よく説得 し、一甘も早く希望と自信を枮えつけるよう根 気よく説得を統けることが大切である。

\section{(O)不定愁訴の治療法}

不定愁訴は、例外なく自律神経のアンバラン スによるものであるから、鍼炎治療の最適応症 でちって、良導絡鍼炎によって自律神経の調整 をはかることが治療の一番の占!道であることは 言うまでもない。

私は良導絡の調整治療をやる事は勿論重要で あるが、一般的鍼炎治療の概念として躯幹!二於 ける治療も大切であるという推等から、

然し良導絡を測定し、その調整をする為に行 
う治療点は、すべて手足の末端にあって、興㝐 点、抑制点に治療をしても、それだけで治療完 了というわけにはいかないのである。従来の鍼 炎治准の概念からしても軀幹部の治燎も又必要 になってくるのである。

私が云う良導带というのは、この軀幹におけ る反応良導点を一定の法則下に統一し、方程式 的に之をまとめ軀幹部の施術の基準としている ものである。従ってこの場合に最も反応良導点 の現れる部分は第七䅡椎の両傍である。

第七䅡椎は一段と高くぼう隆しているが、こ れこそよく注目し一考を要するものであると思 う。この骨が一段と高くなっているのは決して ダテや酔狂でこうたっているのではなく、治療 上、又健康上最も大切な基準となっている為で あると思はれる。古事では之と大椎又は大ぼね と呼び、又、大椎に炎すれば万病に効くとも書 かれている。頭の病気、咽喉の病気、胸部の疾 患等広く之を応用し、古来治療点を求める基準 としている。

\section{○以下スライド説明}

1.38才の婦人、十年来の頭痛、原因不明、 これも第一䅡椎を中心として、明淮に左右 に良導帯が出ている。良導絡の調整と両方 に針尒。

2. 58才の主婦、頭痛、不眠、いらいら等の 症状で来診、之も同じく第七䅡椎の左右か ら頚のつけ根にかけて、良導带を検出、良 導絡の調整点に炎を、良導帯に銊を。

3. 48才婦人（末亡人）気分がいらいらして 落ちつかず、肩甲部、背部に時々痛みがあ り、胸内苦悶等もある。脈が細く速く心悸 六進の症もある。良導帯は第一、第二胸椎 の左右に一直線に出ている。尚前胸部にも 良導带があるので、これ等に鍼療を施した。 4. 49才男子、不眠、消化不良等、これは不 定愁訴というべきか分らないが、少し血圧 も高いようだし精神的疲労もあった。第一 胸椎に良導帯、背部にも反応良導点があっ たのでこれ等に鍼炎治療をした。

以上の四例は何れも 30 回程度の治㙩で全治 している。

\section{(○)考按}

なお、慢性の不眠症や偏頭痛のものは、第一 頚椎の高さに出る良導帯の他にも、風池、天柱 等に治療する必要もあると思はれるし、時とし ては百会等の如きも適当に有効なるツボを選択 して治療することも必要である。

又、婦人科的疾患のある場合や、下琍、消化不 良、便秘等、いろいろな症状に伴ない。それぞ れ、良導帯が必ず生じるものであるからこれを 正確につきとめて治療をすると予期する治療成 績を挙げ得ることは間違いなく、良導絡調整治 療と、良導帯の治療とは車の両輪の如く、今後 の治療に必要なものとなることを確信している。 